Intropica 14(1): 43 - 50

\title{
Cooperative foraging of Paratemnoides nidificator (Balzan, 1888) (Pseudoscorpiones: Atemnidae) on two species of ants (Hymenoptera:Formicidae) in the tropical dry Forest, Colombian Caribbean
}

\author{
Forraje cooperativo de Paratemnoides nidificator (Balzan, 1888) \\ (Pseudoscorpiones: Atemnidae) sobre dos especies de hormigas \\ (Hymenoptera:Formicidae) en el bosque seco tropical, Caribe colombiano
}

\author{
Richard Torres@ ${ }^{1 *}$, Edwin Bedoya $\bigotimes^{2}$ y José Tovar@1 \\ *Corresponding author: richardtorree@gmail.com \\ Received: 15 July 2018 \\ Accepted: 06 December 2018
}

1 Grupo de Investigación en Zoología y Ecología, Universidad de Sucre, Sucre, Colombia

2 Grupo de Investigación en Biodiversidad Marina y Costera (BIODIMARC), Grupo de estudio en Aracnología, (PALPATORES), Universidad de Córdoba, Montería, Colombia

\begin{abstract}
Key words:

Two new cases of cooperative foraging by Paratemnoides nidificator (Balzan, 1888), in ants Atta cephalotes (Linnaeus, 1758) and Dolichoderus bispinosus (Olivier, 1792) are documented. These events were observed in the locality of Santa Inés, municipality of San Marcos, Department of Sucre, Colombian Caribbean. It is the first record of this kind of food-searching behavior in this social species of pseudoscorpions, that preys on the above-mentioned ant species. This means an increase in the number of species that are known as preys, and that constitute the diet of this pseudoscorpion.
\end{abstract}

\section{Resumen}

Palabras clave:

ecología; dieta; Pseudoscorpiones; hormigas; Sucre; Colombia

Dos nuevos casos de forrajeo cooperativo por parte de Paratemnoides nidificator (Balzan, 1888) en hormigas Atta cephalotes (Linnaeus, 1758) y Dolichoderus bispinosus (Oliver, 1792) son documentados. Estos eventos se observaron en la localidad de Santa Inés, municipio de San Marcos, departamento de Sucre, Caribe Colombiano. Esto representa el primer registro de este comportamiento de búsqueda de alimento en estas especies de hormigas por esta especie social de pseudoescorpiones. Se incrementa el número de especies conocidas como presas y que forman parte de la dieta de este pseudoescorpion.

Social behavior and long-term cooperation among cospecifics are relatively rare, the best-known examples are social insects such ants, bees, and termites (Wilson, 1971; 1975; Viera and Agnarsson, 2017). In such societies, individuals are often morphologically specialized, and most contribute to different tasks in the colony (Whitehouse and Lubin, 2005; Viera and Agnarsson, 2017). Generally, pseudoscorpions are solitary animals, but there are a few social species. Recently, social behavior was observed in Paratemnoides nidificator (Balzan, 1888) (Weygoldt, 1969; Tizo-Pedroso and Del-Claro, 2005, 2007; Fernandes et al., 2018). Other animals can be strictly asocial; agonistic interactions are more common than cooperation among cospecifics, most spiders are solitary and aggressive, often cannibalistic, and cooperation is absent (Avilés, 1997; Foelix, 2011; Bilde and Lubin, 2011; Viera and Agnarsson, 2017). Therefore, P. nidificator is a suitable model species to investigate the general characteristics of social pseudoscorpions (Tizo-Pedroso and Del-Claro, 2007). In this sense, subsociality is maternal care that includes several juvenile instars, rather than few (Agnarsson, 2004), and the sociability is characterized by the absence of dispersal of nestmates (Aguiar and Bührnheim, 1998; Viera and Agnarsson, 2017; Tizo-Pedroso and Del-Claro, 2018). 
Sociality is an uncommon phenomenon among arachnids (Avilés, 1997; Choe and Crespi, 1997; García et al., 2016), the most complex cases of sociability occur among spiders and pseudoscorpions, where examples of cooperative species arefound (Zeh and Zeh, 1990; Avilés, 1997; DelClaro and Tizo-Pedroso, 2009; Yip and Rayor, 2014; Viera and Agnarsson, 2017). While cooperative behavior has evolved repeatedly in spiders, it is found only in a small fraction of species (less than $0.05 \%$ ), of spider species (Agnarsson et al., 2006; Avilés, 1997; Bilde and Lubin, 2011; Viera and Agnarsson, 2017). In spiders, food is a critical determinant of sociability, as group size and structure are regulated by the prey size and availability (Whitehouse and Lubin, 2005; Lubin and Bilde, 2007; Guevara et al., 2011; García et al., 2016).

Pseudoscorpions are arachnids present in all terrestrial ecosystems, except polar zones, having cryptic sizes and habits (Weygodlt, 1969; Del-Claro and Tizo-Pedroso, 2009; Tizo-Pedroso and Del-Claro, 2018). Commonly, these animals can be found inhabiting the litter, under rocks, bark of trees and decomposing trunks (Hoff, 1959; Gabbutt, 1962; Weygoldt, 1969; Lee, 1979; Mahnert and Schuster, 1981; Del-Claro and Tizo-Pedroso, 2009; Harvey, 2009; Harvey, 2013; Mahnert, 2014; Bedoya-Roqueme,
2015; Judson, 2016). Pseudoscorpions can be found in many microhabitats such as bat guano, ants and bee nests, and parts of plants (like the Bromeliaceae); also, they are known by their phoretic behavior with birds, insects and mammals (Weygoldt, 1969; Zeh and Zeh, 1992a, b; Cole et al., 1995; Poinar et al., 1998; Aguiar and Bührnheim, 2003; Francke and Villegas-Guzmán, 2006; González et al., 2007).

Likewise, they are generalist predators, they also take advantage of animals smaller than themselves, however, $P$. nidificator has developed hunting strategies to take advantage of large prey (Zeh and Zeh, 1990; TizoPedroso and Del-Claro, 2007; 2018; Filgueiras et al., 2018). Previous studies on diet and feeding behavior in $P$. nidificator, showed that this species can feed on larger prey and capture them (Brach, 1978; Zeh and Zeh, 1990). This species of pseudoscorpion prefers a large variety of prey, mainly insects, but also other arachnids, isopods, and myriapods; all these preys of variable size (table 1) (García et al., 2016; Tizo-Pedroso and Del-Claro, 2007; 2018; Fernandes et al., 2018). Currently, we only have a poor understanding of how $P$. nidificator forages and feeds on different prey items (table 1) (Tizo-Pedroso and Del-Claro, 2018). We described two different cases of foraging on two different ant species by $P$. nidificator.

Table 1. Ant species used as prey by Paratemnoides nidificator (Balzan, 1888) (Atemnidae). New reports of prey for the diet $(*$ )

\begin{tabular}{|c|c|c|c|}
\hline Order & Family & Species & References \\
\hline \multirow[t]{19}{*}{ Hymenoptera } & Formicidae & Acromyrmex octospinosus & García et al., 2016 \\
\hline & & Acromyrmex sp.1 & Tizo-Pedroso and Del-Claro, 2007 \\
\hline & & ${ }^{*}$ Atta cephalotes & This investigation \\
\hline & & Camponotus 3 spp. & Tizo-Pedroso and Del-Claro, 2007 \\
\hline & & Camponotus cf. brevis & García et al., 2016 \\
\hline & & Camponotus cf. substitutus & García et al., 2016 \\
\hline & & Camponotus crassus & Filgueiras et al., 2018 \\
\hline & & Camponotus mus & Filgueiras et al., 2018 \\
\hline & & Camponotus sp. & García et al., 2016 \\
\hline & & Cephalotes atratus & Zeh and Zeh, 1990 \\
\hline & & Chephalotes sp.1 & Tizo-Pedroso and Del-Claro, 2007 \\
\hline & & Chephalotes clypeatus & \\
\hline & & Crematogaster sp. & García et al., 2016 \\
\hline & & *Dolichoderus bispinosus & This investigation \\
\hline & & Ectatomma tuberculatum & García et al., 2016 \\
\hline & & Odontomachus sp. & García et al., 2016 \\
\hline & & Pachycondyla sp. & Tizo-Pedroso and Del-Claro, 2007 \\
\hline & & Pseudomyrmex sp. & García et al., 2016 \\
\hline & & Pseudomyrmex sp.1 & Tizo-Pedroso and Del-Claro, 2007 \\
\hline
\end{tabular}


We observed and described a series of cases of cooperative foraging that took place in the Protective Forest Reserve "Bosque Santa Inés", located at $8^{\circ} 42$ ' 43,8 ” $\mathrm{N}$ and $75^{\circ} 13^{\prime} 39.3^{\prime}$ W, municipality of San Marcos, Department of Sucre, Colombian Caribbean (figure 1a). Commonly, this area is part of the tropical dry forest's ecosystem (figure 1b). Between the months of March and April of 2018, night sampling was carried out systematically (20: 00 - 23: $00 \mathrm{~h})$.
For three days, the method of collecting unrestricted free was used for each sampling, the bark of live trees and of decomposing trunks was examined, in order to record cases of foraging by pseudoscorpions. The registered cases of foraging were photographed, and the specimens were collected and preserved in $70 \%$ ethanol, and subsequently, examine them in the laboratory. Additionally ecological data was recorded.

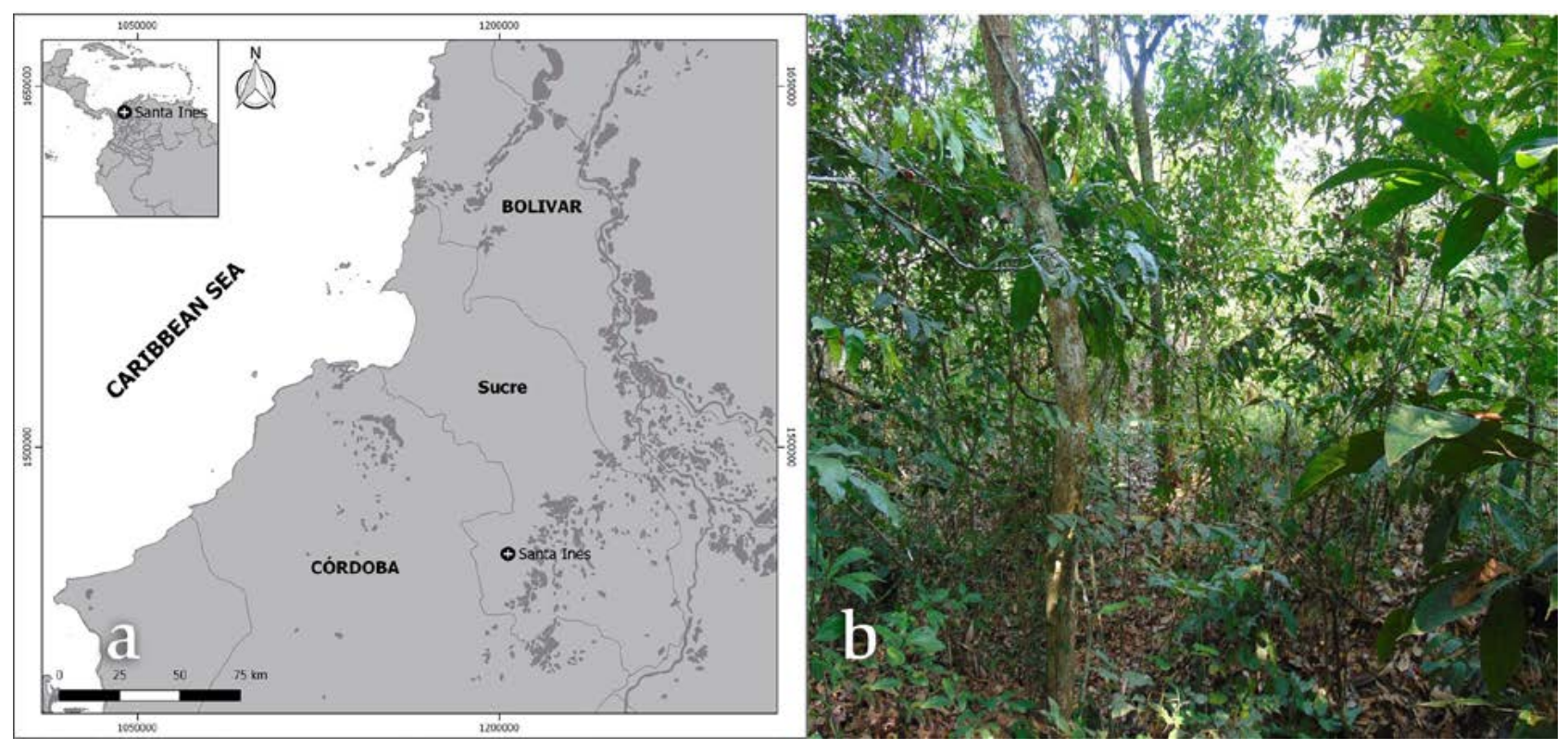

Figure 1. Cooperative foraging of Paratemnoides nidificator (Balzan, 1888): a. Locality where the cases of cooperative foraging were recorded. b. Dry forest of Santa Inés, Department of Sucre, Colombian Caribbean.

These cases were observed in the loose bark of five trees, with a diameter of $50 \mathrm{~mm}$, in areas surrounding the tree where several colonies of pseudoscorpions were present. The specimens collected were dissected, a leg I and IV, a chelicera and a pedipalp, of which the chela was separated. The dissected portions were collected in a MicroVial and preserved in $70 \%$ ethanol in the same vial as the rest of each specimen. The specimens were studied using temporary mounts on glycerin, a process carried out in the Entomology laboratory of the University of Sucre. The specimens were studied with the help of a microscope Carl Zeiss, plus Axiostar, Germany. Multifocal photographs were taken in the Microscopy laboratory of the Universidad de Cordoba, with an HD digital camera attached to the Carl Zeiss stereomicroscope, Axiostar, and then put together using the image stacking software AxioVision Carl Zeiss (Rel.4.8.2. SP3). The specimens of pseudoscorpions collected were identified as Paratemnoides nidificator (figure 2 a y b), using the taxonomic keys for families and genera of Harvey (1992); Mahnert and Adis (2002) and the descriptions made by Balzan (1890); Beier (1932); Klausen (2005). The ants were identified as Atta cephalotes (Linnaeus, 1758) and Dolichoderus bispinosus (Oliver, 1792) (figure 3 a y b), using the taxonomic keys proposed by Mackay and Mackay (1989), Bolton (1994);(2003), Hölldobler and Wilson (1990), Palacio and Fernández (2003) and Ortíz and Fernández (2011). All collected specimens were deposited in the Collection of The Entomology Laboratory, Universidad de Sucre, Colombia (LEUS) with the voucher number LEUS-C010 (Pseudoscorpiones), and LEUS-F102 (Ants). 


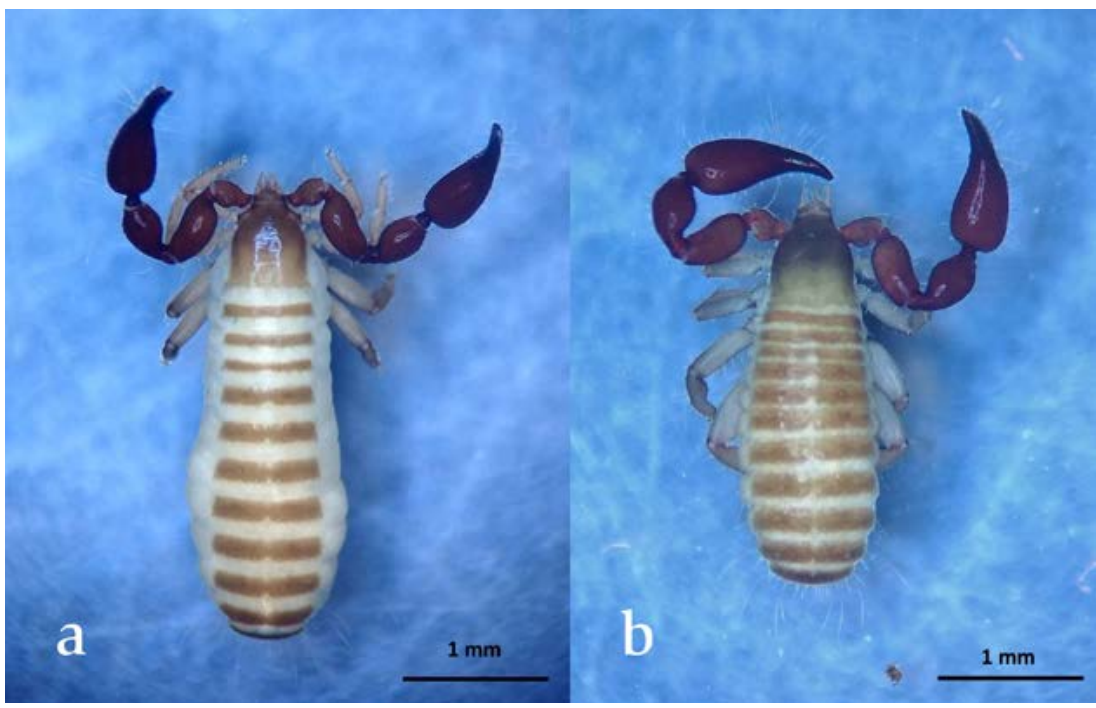

Figure 2. Specimens collected: a. Habitus, Paratemnoides nidificator female, dorsal view. b. Habitus, male, dorsal view.

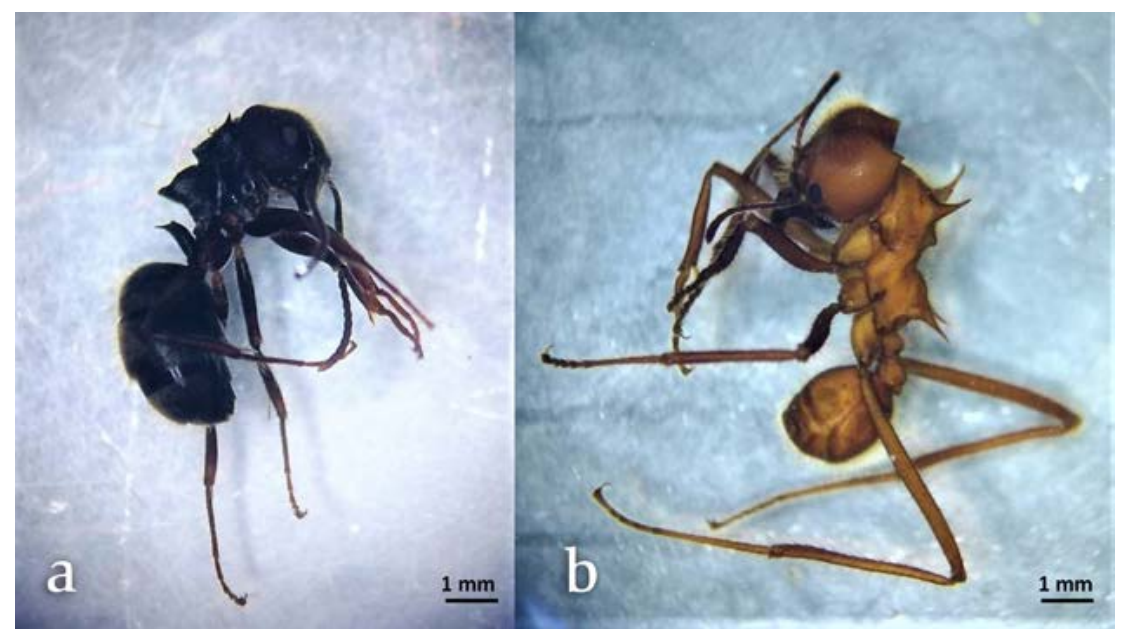

Figure 3. Ants, specimens collected: a. Habitus, Atta cephalotes, lateral view. b. Habitus, Dolichoderus bispinosus, lateral view.

Ants are eusocial organisms, characterized by cooperative care of young, which coincides with generations of workers in the colony and the development of an advanced caste system (Wilson, 1971). In this sense, A. cephalotes, commonly known as pruning ant, forager or leaf cutter, is considered to be one of the most widely dispersed ants in Colombia's forests and agrarian systems (Villanueva et al., 2016). It is considered to be a plague as it causes defoliation (Della Lucia, 2011; Montoya-Lerma et al., 2012; Villanueva et al., 2016). Its diet is varied and it uses the material of the plant for the growth of the fungus Leucoagarycus gongylophorus (Escobar et al., 2002; the most widely dispersed species of genus Dolichoderus in Colombia (Ortíz and Fernández, 2007), and it has a certain preference for canopies, which are particularly abundant in isolated areas, for instance, treetops (Harada and Adis, 1998; Cuezzo, 2003; Chacón et al., 2014). While these ants were gathering food, three $P$. nidificator males (located outside the bark) attacked an individual (ant) of A. cephalotes, (figure 4a), holding it strongly by the legs; once the prey was neutralized, it was dragged by its legs by two pseudoscorpions, and it was held by two more individuals who were under the bark (figure 4b). Finally, several pseudoscorpions came out from under the bark and began feeding on the ant; the colony was composed 
by several individuals of different stages of nymph and adults (of different sex), 4 protonymphs, 5 tritonymphs, 5 females, and 5 males, respectively.

Likewise, it was observed in the loose bark of five trees, two to three colonies of $P$. nidificator on average (with 3 to
4 males out of colonies), they attacked several ants of the species $D$. bispinosus, holding them strongly by their legs, and finally when immobilizing the prey, it was dragged into the refuge (figure. $4 \mathrm{c}-\mathrm{d}$ ). In the same tree where this event was observed, we observed between two to three colonies performing the same behavior.
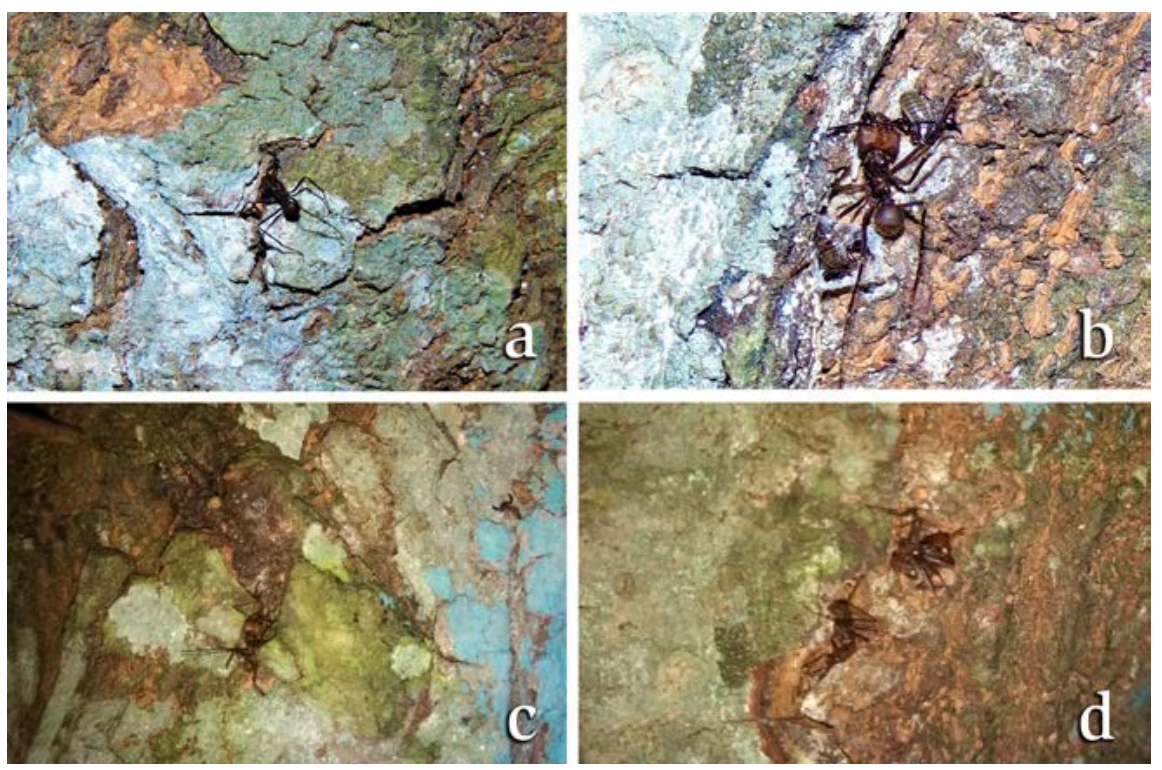

Figure 4. Cooperative foraging on Atta cephalotes L. and Dolichoderus bispinosus O.: a. Shot of the prey. b. Immobilization captured prey. c. Dragging the ant. d. Introducing the ant inside the colony.

The species $P$. nidificator is considered a widely dispersed species in America, and lives in Central and South America, in the bark of decomposing trunks and living trees (Harvey, 2013). It is considered to be the only social species of pseudoscorpions: it lives in large colonies maintained by a high intraspecific tolerance and exhibit cooperative behaviors (Hahn and Matthiessen, 1993; Tizo-Pedroso and Del-Claro, 2018; Fernandes et al., 2018). In general, it exhibits cooperative parental care and division of labors in the colonies (Tizo-Pedroso and Del-Claro, 2005, 2007, 2011; Del-Claro and Tizo-Pedroso, 2009).

Some authors, such as Zeh and Zeh (1990), and TizoPedroso and Del-Claro (2018), suggest that this species of pseudoscorpion is a generalist predator. It feeds on a great variety of prey and in contrast to other groups of pseudoscorpions, it includes large preys in their diet. In addition, the plasticity of food is directly related to the cooperative search (Tizo-Pedroso and Del-Claro, 2007; 2011); they can subdue and capture preys almost four times larger than them in body size. Some authors, such as Tizo-Pedroso and Del-Claro (2007), (2018); Fernandes et al. (2018), and Filgueiras et al. (2018), who studied the foraging ecology and social life of $P$. nidificator, documented the use of more than 60 different preys in 15 taxonomic groups, including dangerous organisms, such as ants and spiders. Likewise, García et al. (2016), evaluated how selective P. nidificator is of its of prey. He determined there are 14 preys in 7 taxonomic groups. Similarly, Fernandes et al., (2018) evaluated the selectivity of prey using ants of the genus Camponotus. In spite of the above-mentioned information, the fact that the species Atta cephalotes and Dolichoderus bispinosus, is a part of the diet of $P$. nidificator (table 1).

Cooperative hunting not only increases the chances $P$. nidificator has of catching prey, but also its chances of catching a large prey, which allows mutual tolerance between individuals of the same colony, and is presented as an important step in the evolution of the prey, non-territorial permanent and social behavior (Zeh and Zeh, 1990; TizoPedroso and Del-Claro, 2007). In small colonies, such as those observed in this research, it usually involves few individuals; the feeding process tends to favor the juveniles 
because the prey is dragged to the colony (Tizo-Pedroso and Del-Claro, 2018). Adults are mainly dedicated to capturing and subduing small preys and then give them to the nymphs as food (Tizo-Pedroso and Del-Claro 2005, 2007, 2018). This behavior was evident in the documented cases of the two species of ants $A$. cephalotes, and $D$. bispinosus, which was dragged to the interior of the colony, under the bark. The adults remain in a defensive position, while the nymphs are feeding on the prey, and tend to wait for the nymphs to leave the prey to approach it and feed on it, as well (Tizo-Pedroso and Del-Claro 2005; 2007). The combination of tasks related to food and parental care is considered to be essential for the division of labor, and a key effort for mantaining the proper growth of the colonies and the development of new individuals who will act as workers in the colonies (TizoPedroso and Del-Claro 2011; 2018).

This species of social pseudoscorpion has been classified as an euryphagous predator. Additionally, it has been noted that it feeds selectively on some species of ants of Camponotus and Acromyrmex genera (Zeh and Zeh, 1990; Hahn and Matthiesen, 1993; García et al., 2016; Fernandes et al., 2018; Tizo-Pedroso and Del-Claro, 2018), which suggests that ants are an important part of the diet of this social group of arachnids. Therefore, these cases, that were observed and documented, constitute the first case of cooperative foraging of individuals of $P$. nidificator in ants A. cephalotes, and D. bispinosus. This a new contribution to the knowledge of the diet of this social pseudoscorpion.

\section{Acknowledgments}

We express our gratitude to Pedro Luis Atencia, biologist from the Universidad de Sucre, Colombia, because of his assistance and help in the collection of the studied material. To the Entomology Laboratory of the University of Sucre, Colombia, and the Zoology Laboratory of the University of Córdoba, Colombia for their assistance and collaboration.

\section{References}

Agnarsson, I. 2004. Morphological phylogeny of cobweb spiders and their relatives (Araneae, Araneoidea, Theridiidae). Zoological journal of the Linnean Society 141: 447-626.

Agnarsson, I., Avilés, L., Coddington, J. A. and Maddison, W. P. 2006. Sociality in theridiid spiders: repeated origins of an evolutionary dead end. Evolution 60: 2342-2351.

Aguiar N.O. and Bührnheim P.F. 1998. Phoretic pseudoscorpions associated with flying insects in Brazilian Amazonia. Journal 48 of Arachnology 26: 452 - 459.
Aguiar, N.O. and Bührnheim, P.F. 2003. Pseudoscorpiones (Arachnida) Da Vegetacao De Sub-Bosque Da Floresta Primaria Tropical De Terra Firme, (Coari, Amazonas, Brasil). Acta Amazonica 33: 515-526.

Avilés, L. 1997. Causes and consequences of cooperation and permanent-sociality in spiders. In: Choe J.C. and Crespi, B.J. Editor. The evolution of social insects and arachnids. Cambridge University Press, Cambridge.

Balzan, L. 1890. Revisione dei Pseudoscorpioni del Bacino dei Fiumi Paranà e Paraguay nell'America meridionale. Annali del Museo Civico di Storia Naturale di Genova (2a) 9: 401-454.

Bedoya-Roqueme, E. 2015. Una nueva especie de Paraliochthonius (Pseudoscorpiones: Chthoniidae: Tyrannochthoniini) de Colombia. Revista Ibérica de Aracnología 26: 49-54.

Beier, M. 1932. Pseudoscorpionidea II. Subord. C. Cheliferinea. Tierreich 58: i-xxi, 1-294.

Bilde, T. and Lubin, Y. 2011. Group living in spiders: cooperative breeding and coloniality. In: Brach, V. 1978. Social behavior in the pseudoscorpion Paratemnus elongatus (Banks) (Pseudoscorpionida, Atemnidae). Insectes Sociaux 25: 3-11.

Bolton, B. 1994. Identification guide to the ant genera of the world. Harvard University, Massachussetts.

Bolton, B. 2003. Synopsis and classification of Formicidae. Memoirs of the American Entomological Institute 71: 1-370.

Brach, V. 1978. Social behavior in the pseudoscorpion Paratemnus elongatus (Banks) (Pseudoscorpionida, Atemnidae). Insectes Sociaux 25:3-11.

Choe, J.C. and Crespi, B.J. 1997. The evolution of social behaviour in insects and arachnids. Cambridge University Press, Cambridge.

Chacón, de U.P., Valdés-Rodríguez, S., Hurtado-Giraldo, H. and Cleopatra, P.M. 2014. Hormigas arbóreas del Parque Nacional Natural Gorgona (Pacífico de Colombia). Revista Biología Tropical 62(1): 277-287.

Cole, D.C., Elgar, M.A. and Harvey, M.S. 1995. Associations between Australian pseudoscorpions and ants. Psyche (Stuttg) 101: 221-227.

Cuezzo, F. 2003. Subfamilia Dolichoderinae. In: Fernández, F., Editores. Introducción a las hormigas de la región Neotropical. Instituto de Investigación de Recursos Biológicos Alexander Von Humboldt, Bogotá, Colombia. 
Del-Claro, K. and Tizo-Pedroso, E. 2009. Ecological and evolutionary pathways of social behavior in Pseudoscorpions (Arachnida: Pseudoscorpiones). Acta Ethologica 12:13-22.

Della Lucia, T.M.C. 2011. Formigas-cortadeiras: da bioecologia ao manejo. Viçosa, M.G: Ed. Universidade Federal de Viçosa, Viçosa Minas Gerais.

Escobar, D.R., García, C.F., Rentería, N.Y. and Neita, M, J.C. 2002. Manejo y control de hormiga arriera (Atta spp. \& Acromyrmex spp.) en sistemas de producción de importancia económica en el departamento del Chocó. Cartilla 1 y 2. Ministerio de Agricultura- PRONATTA-Universidad Tecnológica del Chocó. CO.

Fernandes, R.M., Tizo-Pedroso, E. and Del-Claro, K. 2018. Colony size, habitat structure, and prey size shape the predation ecology of a social pseudoscorpion from a tropical savanna. Behavioral Ecology and Sociobiology 72:103.

Filgueiras, R.R., Gomes, F.C., Ferreira, A.S.T., Tizo-Pedroso, E. and Del-Claro, K. 2018. Cooperative foraging in Neotropical pseudoscorpions: effects of prey changes on behavioral adjustments of colonies. Acta Ethologica 21(3): 153-161.

Foelix, R.F. 2011. Biology of spiders. Oxford University Press, Oxford.

Francke, O.F. and Villegas-Gúzman, G.A. 2006. Symbiotic relationships between Pseudoscorpions (Arachnida) and packrats (Rodentia). Journal of Arachnology 34: 289-298.

Gabbutt, P. 1962. Nest of the marine falsescorpion. Nature London 196: 97-98.

García, L.F., Gonzalez-Gómez, J.C., Valenzuela-Rojas, J.C., Tizo-Pedroso, E. and Lacava, M. 2016. Diet composition and prey selectivity of Colombian populations of a social pseudoscorpion. Insectes Sociaux 63: 635-640.

Gonzalez, V.H., Mantilla, B. and Mahnert, V. 2007. A new host record for Dasychernes inquilinus (Arachnida, Pseudoscorpiones, Chernetidae), with an overview of pseudoscorpion-bee relationships. Journal of Arachnology 35: 470-474.

Guevara, J., Gonzaga, M.O., Vasconcellos-Neto, J. and Avilés, L. 2011. Sociality and resource use: insights from a community of social spiders in Brazil. Behavioral Ecology 22: 630-638.

Hahn, N.S. and Matthiessen, F.A. 1993. Notas biológicas sobre Paratemnus minor (Pseudoscorpiones, Atemnidae). Revista Brasileira de Biologia 53: 571-574.

Harada, A.Y. and Adis, J. 1998. Ants obtained from tres of a "Jacareúba" (Calophyllum brasiliensi) forest plantation in central Amazonia by canopy fogging: first results. Acta Amazonica 28: 309-318.

Harvey, M.S. 1992. The phylogeny and classification of the Pseudoscorpionida (Chelicerata: Arachnida). Invertebrate Taxonomy 6: 1373-1435.

Harvey, M.S. 2009. The first Australasian species of the genus pseudoscorpion halophilic Paraliochthonius (Pseudoscorpiones: Chthoniidae). Records of the Western Australian Museum 25: 329-344.

Harvey, M.S. 2013. Pseudoscorpions of the World, version 2.0. Western Museum Australian, Perth._URL:_Http:www. museum.wa.gov.au/catalogs/pseudoscorpion. Consulted: June 15, 2018).

Hoff, C.C. 1959. The ecology and distribution of the pseudoscorpions of north-central New Mexico. University New Mexico. Publishing Biological 8: 1-68.

Hölldobler, B. and Wilson, E. 1990. The Ants. Harvard University, Massachussetts.

Judson, M.L. 2016. Pseudoscorpions (Arachnida, Chelonethi) in Mexican amber, with a list of extant species associated with mangrove and Hymenaea trees in Chiapas. Boletín de la Sociedad Geológica Mexicana 68: 57-79.

Klausen, F.E. 2005. The male genitalia of the family Atemnidae (Pseudoscorpiones). Journal of Arachnology 33: 641-662.

Lee, V.F. 1979. The maritime pseudoscorpions of Baja California, México (Arachnida: Pseudoscorpionida). Occasional Papers of the California Academy of Sciences 131:1-38.

Lee, V.F. 1979. The maritime pseudoscorpions of Baja California, México (Arachnida: Pseudoscorpionida). Occasional Papers of the California Academy of Sciences 131:1-38.

Lubin, Y. and Bilde, T. 2007. The evolution of sociality in spiders. Advances in the Study of Behavior 37: 83-145.

Mahnert, V. and Adis J. 2002. Pseudoscorpiones. In: Adis, J., Editor Amazonian Arachnida and Myriapoda. Pensoft Publisher, Moscow.

Mahnert, V. 2014. Pseudoscorpions (Arachnida: Pseudoscorpiones) from the Galapagos Islands (Ecuador). Revue Suisse de Zoologie 121: 135-210.

Mahnert, V. and Adis, J. 2002. Pseudoscorpiones. Pp: 367-380, En: Adis, J. (eds), Amazonian Arachnida and Myriapoda. Pensoft Publisher, Sofía - Moscow. 
Mahnert, V. and Schuster, R. 1981. Pachyolpium atlanticum sp. nov., ein Pseudoskorpion aus der Gezeitenzone der Bermudas-Morphologie und Ökologie (Pseudoscorpiones: Olpiidae). Revue Suisse de Zoologie 88: 265-273.

Mackay, W.P. and Mackay, E.E. 1989. Clave de los géneros de hormigas en México (Hymenoptera: Formicidae). II Simposio Nacional de Insectos Sociales. México.

Montoya-Lerma, J., Giraldo-Echeverri, C., Armbrecht, I., Farji-Brener, A. and Calle, Z., 2012. Leaf-cutting ants revisited: Towards rational management and control. International Journal of Pest Management 58 (3): 225-247.

Ortíz, M.C. and Fernández, F. 2011. Hormigas Dolichodeirus lund (Formicidae: Dolichoderinae) en Colombia. Universidad Nacional de Colombia, Instituto de Ciencias Naturales, Bogotá, Colombia.

Palacio, E. and Fernández, F. 2003. Clave para las subfamilias y géneros. In Fernández, F. Editores. Introducción a las hormigas de la región Neotropical). Instituto de Investigación de recursos Biológicos Alexander Von Humboldt, Bogotá D.C.

Poinar, G.O., Ćurčić, B.P.M, Jr., and Cokendolpher, J.C. 1998. Arthropod phoresy involving pseudoscorpions in the past and present. Acta Arachnology 47: 79-96.

Tizo-Pedroso, E. and Del-Claro, K. 2005. Matriphagy in the neotropical pseudoscorpion Paratemnoides nidificator (Balzan, 1888) (Atemnidae). Journal of Arachnology 33(3): 873-877.

Tizo-Pedroso, E. and Del-Claro, K. 2007. Cooperation in the neotropical pseudoscorpion, Paratemnoides nidificator (Balzan, 1888): feeding and dispersal behavior. Insectes Sociaux 54: 124-131.

Tizo-Pedroso, E. and Del-Claro, K. 2011. Is there division of labor in cooperative pseudoscorpions? An analysis of the behavioral repertoire of a tropical species. Ethology 117: 498-507.
Tizo-Pedroso, E. and Del-Claro, K. 2018. Capture of large prey and feeding priority in the cooperative pseudoscorpion Paratemnoides nidificator. Acta Ethologica 21: 109-117.

Viera, C. and Agnarsson, I. 2017. Parental Care and Sociality. In: Viera, C. and Gonzaga, M.O. Editor. Behaviour and Ecology of Spiders, Contributions from the Neotropical Region. Springer International Publishing, Gewerbestrasse, Cham, Switzerland.

Villanueva, D. Rocío García, R. and James-Montoya, J.L. 2016. Nidos de Atta cephalotes (Hymenoptera: Myrmicinae) en Sistemas Cafeteros Contrastantes, Departamento del Cauca, Colombia. Boletín Científico del Centro de Museos de la Universidad de Caldas 20(2): 138-150.

Weygoldt, P. 1969. The biology of pseudoscorpions. Harvard University Press, Cambridge.

Whitehouse, M.E. and Lubin, Y. 2005. The functions of societies and the evolution of group living: spider societies as a test case. Biological Reviews 80: 347-361.

Wilson, E.O. 1971. The insect societies. Harvard University Press, Cambridge.

Wilson, E.O. 1975. Sociobiology: the new synthesis. Harvard University Press, Princeton.

Yip, E.C. and Rayor, L.S. 2014. Maternal care and subsocial behaviour in spiders. Biological Reviews 89:427-449.

Zeh, D.W. and Zeh, J.A. 1992a. Dispersal-generated sexual selection in a beetle-riding pseudoscorpion. Behavioral Ecology and Sociobiology 30: 135-142.

Zeh, D.W. and Zeh, J.A. 1992b. On the function of harlequin beetle-riding in the pseudoscorpion, Cordylochernes scorpioides (Pseudoscorpionida: Chernetidae). Journal of Arachnology 20: 47-51.

Zeh, J.A. and Zeh. D.W. 1990. Cooperative foraging for large prey by Paratemnus elongatus (Pseudoseorpionida, Atemnidae). Journal of Arachnology 18: 307-311.
How to cite: Torres, R., Bedoya, E. and Tovar, J. 2018. Cooperative foraging of Paratemnoides nidificator (Balzan, 1888) (Pseudoscorpiones: Atemnidae) on two species of ants (Hymenoptera:Formicidae) in the tropical dry Forest, Colombian Caribbean. Intropica 14(1): 43-50. DOI: hhttp://dx.doi.org/10.21676/23897864.2697. 